\title{
A celebração da moral heroica na Ilíada de Homero
}

\author{
Ana Gabrecht \\ Faculdade Saberes/ Vitória-ES \\ anagabrecht@gmail.com
}

\section{RÉSUMÉ}

Cet article essaye une définition de la puissance de basileús (roi) homérique comme il est décrit dans l'Iliade. Le pouvoir du monarque est appuyée par des éléments symboliques qui l'entourent, qu'il s'agisse de ses attributs tels que la couronne et son sceptre ou d'attributs moraux tels que le courage sur le champ de bataille. Comme l'Iliade est un poème de la guerre, c'est une ouvré que représente la morale héroïque, le guerrier code de valeurs prévalant dans la soi-disant homérique Période (siècle XII-VIII a.C). Dans le monde homérique, est en temps de guerre, bien plus que de paix, le héros - le plus souvent, un basileús - peuvent montrer leur savoir-faire et assurer ainsi sa position dans la hiérarchie sociale.

MOTS-CLÉS: Homère; Iliade; royauté; honneur; gloire.

A epopeia homérica é a celebração da moral heroica. Moral que pressupõe a existência de uma tradição de poesia oral, repositória de uma cultura comum, que funciona para o grupo como memória social. Não há kléos (glória) senão cantada. O herói homérico não luta e morre esperando obter recompensas em uma outra vida, ${ }^{1}$ mas busca a glória celebrada na poesia épica.

Os heróis homéricos são guiados por um rígido código de valores, norteados principalmente pelas ideias de timé (honra), areté (virtude, excelência), kléos (glória), géras (privilégio). Sendo um poema bélico, os valores apresentados na Ilíada são essencialmente os de uma aristocracia guerreira, que necessita mostrar sua destreza em campo de batalha. De acordo com a moral heroica predominante no mundo dos poemas, os reis devem ser guerreiros proeminentes para, assim, desfrutar do poder e dos privilégios. Gozam desses na devida proporção de suas habilidades bélicas. ${ }^{2}$

\footnotetext{
${ }^{1}$ A principal razão pela qual é tão importante para o herói homérico obter honra e glória no campo de batalha é porque, no mundo da Ilíada, não há uma significante vida após a morte. A palavra psiqué, normalmente traduzida como "alma", não tem, em Homero, a importância intelectual ou espiritual que irá adquirir na Grécia posteriormente. Na Ilíada, refere-se a uma entidade que se desprende do corpo no momento da morte - ou durante um desmaio, nesse caso, retornando ao corpo - e migra para o Hades (espécie de inferno). Lá, torna-se uma sombra do que tinha sido a pessoa quando viva, sem consciência, nem mesmo inteligência. Apenas uma fumaça sem significante existência física ou mental cf. Schein, S. L. The mortal hero. An introduction to Homer's "Iliad". Berkeley: University of California Press, 1984, p. 68. Sendo um guerreiro valoroso, o herói continuará a existir se seu renome subsistir imperecível, em vez de desaparecer no anonimato cf. Vernant, J.-P. Entre o mito e a política. São Paulo: Edusp, 2001, p. 411.

${ }^{2}$ Cf. McGlew, J. F. Tyranny and political culture in Ancient Greece. Ithaca: Cornell University Press, 1996, p. 53.
} 
O estudioso da guerra na Idade das Trevas, Hans Van Wees, ${ }^{3}$ chama a atenção para o fato de que, na Ilíada, todas as cenas de combate são dominadas pelas figuras dos líderes. É em tempo de guerra, muito mais que em tempo de paz, que o basileús (rei) pode mostrar suas habilidades e assim assegurar sua posição de liderança.

Uma das principais funções do rei no mundo homérico é o comando militar. Embora esteja muito velho para o combate, o basileús pode delegar seus poderes ao futuro sucessor, como faz Peleu, rei da Fítia, que, não podendo participar da Guerra de Troia, envia como representante seu filho Aquiles, no comando de seus homens, os chamados mirmidões. ${ }^{4}$

Finley ${ }^{5}$ destaca a aparente desorganização dos combates na Ilíada:

A confusão aí é indescritível. Ninguém comanda ou dá ordens. Entrase e sai-se da batalha a seu bel-prazer; cada qual escolhe seu adversário; agrupam-se e reagrupam-se por razões puramente pessoais. Essa desorganização não encontra sua origem na falência do plano de batalha previsto, mas traduz o desinteresse do poeta por tudo aquilo que não diz respeito aos seus heróis enquanto indivíduos.

Apesar dessa impressão de confusão nos combates que se tem ao ler a Ilíada, há um comandante principal que conduz a ação. Nos assuntos bélicos, o ideal é que haja um líder supremo que comande a empresa, assim como Agamêmnon é o comandante da expedição grega a Troia. Conforme as palavras que o poeta põe na boca de Odisseu: ${ }^{6}$ "Não é bom! Que um rei, um só, nos comande e encabece..." Apesar de nem sempre ser obedecido, é Agamêmnom quem dita as ordens no exército aqueu, assim como é Heitor que o faz no lado troiano. Para fazer cumprir suas ordens, o basileús exerce sua thémis ${ }^{7}$ e tem o direito sobre a vida e a morte de todos. Ameaçando os soldados, Agamêmnon ${ }^{8}$ diz:

${ }^{3}$ Cf. Van Wees, H. Kings in combat: battles and heroes in the "Iliad". Classical Quarterly. Oxford, vol. XXXVIII, n. 1, p. 1-24, 1988.

${ }^{4}$ Cf. Homero. Ilíada. Tradução de Haroldo de Campos. São Paulo: Arx, 2003. Vol. I/ II (IX, 252; XI, 783).

${ }^{5}$ Cf. Finley, M. I. O mundo de Ulisses. Lisboa: Presença, 1988, p. 71.

${ }^{6}$ Cf. Ilíada II, 204-5.

${ }^{7}$ Finley (op. cit, p. 75) informa que esse termo é intraduzível. Dom dos deuses e signo de vida civilizada, significa por vezes o costume justo, as regras de procedimento, a ordem social e outras vezes, simplesmente, a vontade dos deuses (revelada por um áugure), quase sem implicar a ideia de justiça. Pode-se definir o termo como tradição ou costume transmitido oralmente, sendo aplicada somente em casos concretos. O recurso a thémis confirma o caráter costumeiro do procedimento (Trabulsi, J. A. D. Ensaio sobre a mobilização política na Grécia Antiga. Belo Horizonte: UFMG, 2001, p. 26).

${ }^{8}$ Cf. Ilíada II, 391-3. 
E aquele que eu surpreenda longe do combate, querendo resguardar-se junto às naves curvas, este não fugirá dos cães e dos abutres.

Para falar da realeza que existe em Esparta, Aristóteles $^{9}$ utiliza-se do exemplo de Homero. O filósofo fala dos poderes supremos de Agamêmnon, durante a Guerra de Troia:

O rei não tem o direito de matar, a não ser numa única atribuição do poder real, como os reis antigos aos quais a lei dava o direito de ferir de morte, nas expedições militares. Há disto uma prova em Homero: Agamêmnon suportava as injúrias nas assembleias gerais; mas em campanha ele tinha até o direito de matar.

Para corroborar sua afirmação, Aristóteles utiliza-se do mesmo trecho de Homero citado acima.

O poeta da Ilíada faz uma conexão entre ser líder de um contingente de homens e ser excelente guerreiro. Os chefes são sempre escolhidos dentre os melhores guerreiros, dentre aqueles que os acompanham. Sobre Sarpédon, Homero diz que é "o melhor dos seus muitos guerreiros". ${ }^{10}$ Heitor é descrito como "o mais forte dos guerreiros de Troia". ${ }^{11}$ Aquiles, ${ }^{12}$ Agamêmnon, ${ }^{13}$ Aias ${ }^{14}$ e Diomedes ${ }^{15}$ são chamados, cada um, de "o melhor dos Aqueus",

É no calor do combate que o herói demonstra toda sua areté (virtude, excelência) e consegue obter timé (honra). A distinção entre quem é agathós ${ }^{16}$ (bom) e quem é kakós (mau) faz-se no campo de batalha de acordo com a habilidade bélica. ${ }^{17}$ Nestor dirige-se a Agamêmnon, dizendo: ${ }^{18}$

Isso feito e seguindo-te

os Gregos, saberás que chefes, que guerreiros

\footnotetext{
${ }^{9}$ Cf. Arìstóteles. A Política. Tradução de Roberto Leal Ferreira. São Paulo: Martins Fontes, 2002. Livro III, cap. IX, § 2 .

${ }^{10}$ Cf. Ilíada XVI, 551.

${ }^{11}$ Cf. Ilíada VI, 460.

${ }^{12}$ Cf. Ilíada XVI, 271-2.

${ }^{13}$ Cf. Ilíada II, 579-80.

${ }^{14}$ Cf. Ilíada II, 768.

${ }^{15}$ Cf. Ilíada V, 414.

${ }^{16}$ Uma definição mais completa de agathós é dada por Vernant, op. cit., p. 408: "Significa [...] que um homem é de boa cepa, rico, belo e poderoso e que possui as virtudes e a nobreza de alma semelhantes ao ideal grego do homem completo, do homem de coragem".

17 Cf. Adkins, A. W. H. Merit and responsibility. A study in Greek values. Chicago: University of Chicago Press, 1975, p. 32.

${ }^{18}$ Cf. Ilíada II, 364-8.
} 
vacilam, quais são bravos, cada um por si lutando. Saberás se é o mal-querer dos deuses, ou a moleza inútil de homens que te tolhe.

O status e o privilégio do rei homérico são adquiridos pelo seu nascimento, mas devem ser sustentados pela sua capacidade guerreira. Isso assegura a sua posição e a da sua descendência. ${ }^{19}$ Ao basileús não basta apenas herdar o apanágio real, é preciso justificá-lo. Agamêmnon é criticado por Aquiles por ter a proeminência nos espólios de guerra - um dos privilégios reais —, mas não se destacar como guerreiro. O herói assim se dirige ao comandante da expedição: ${ }^{20}$

Olho de cão e coração de cervo! Bronco de vinho! Nunca ousaste, armado, com teu poyo enfrentar um combate, nem seguiste os bravos na luta de emboscadas. Tens pavor à morte. Mais fácil é no vasto campo dos Aqueus Esbulhar do seu bem a quem te contradiz. Devora-povo! Rei dos Dânaos? Rei dê nada.

O rei tem uma série de deveres. Um deles é esforçar-se no campo de batalha. Somente assim, o basileús pode retribuir à comunidade o respeito que lhe é demonstrado. Sendo valoroso no combate, o líder estende suas conquistas ao povo. Nesse aspecto, Heitor é um caso ilustrativo. Ao lamentar a morte do herói troiano, sua mãe, Hécuba, exclama: "Vivo, eras um deus, uma glória grandiosa para Troia". ${ }^{21}$ Sendo vitorioso na guerra, o rei homérico glorifica seu povo. ${ }^{22}$

O discurso que Sarpédon dirige a Glauco ${ }^{23}$ é famoso por exprimir os deveres do basileus no campo de batalha e as honras que lhe cabem.

Primeiros dos Lícios, cabe-nos arrostar, firmes, a luta ardente, para que os Lícios, fortes-couraças, repitam: "Não sem glória, na Lícia, nossos reis governam, comendo carnes nobres de vitela, vinho sabor-de-mel bebendo em copas; mas na luta postam-se na dianteira, excelem no valor."

\footnotetext{
${ }^{19}$ Cf. Van Wees, op. cit., p. 18.

${ }^{20}$ Cf. Ilíada I, 225-31.

${ }^{21}$ Cf. Ilíada XXII, 433-4.

${ }^{22}$ Cf. Van Wees, op. cit., p. 20.

${ }^{23}$ Cf. Ilíada XII, 315-21.
} 


\begin{abstract}
Antes ainda, Sarpédon questiona a Glauco: ${ }^{24}$
\end{abstract}
Por que somos honrados

— os assentos mais nobres, as carnes melhores -

em Lícia, nos festins, copas copiosas, feito

deuses? Extenso trato de terra [temenos] nos deram

por domínio, vizinho ao Xanto, plantações,

semeaduras de trigo.

Os privilégios particulares da realeza homérica são enunciados por certo número de termos que remetem à honra e às honras. ${ }^{25}$ Dentro do código de valores homérico, destacam-se, em particular, as noções de géras e de timé. Ambos os termos estão intrinsecamente interligados entre si. Vê-se que os termos são quase indissociáveis. Vários autores propuseram-se a definir timé em Homero, mas sempre relacionado com o termo géras.

Benveniste $^{26}$ define timé como um dos apanágios reais - como também o é o geras - que designa o quinhão de honra régia que os deuses recebem do destino (Moîra) e os homens, de Zeus. Géras seria a parte de honra suplementar ocasionalmente concedida pelos súditos ao rei e, distintiva de sua dignidade.

Em uma sociedade guerreira como é a descrita nos poemas homéricos, ganhar honra e glória torna significativa uma vida breve e permite ao herói destacar-se aos olhos dos outros. ${ }^{27}$ Isso está implícito no próprio conceito de honra, tal como é definido por Pitt-Rivers: ${ }^{28}$

Honra é o valor que uma pessoa tem aos seus próprios olhos mas também aos olhos da sociedade. É a sua apreciação de quanto vale, da sua pretensão a orgulho, mas é também o reconhecimento dessa pretensão, a admissão pela sociedade da sua excelência, do seu direito a orgulho [grifo do autor].

\footnotetext{
${ }^{24}$ Cf. Ilíada XII, 310-5.

25 Cf. Benveniste, E. O vocabulário das instituições indo-europeias. Vol. II: Poder, Direito, Religião. Campinas: UNICAMP, 1995, p. 43.

${ }^{26}$ Cf. Benveniste, op. cit.

${ }^{27}$ Cf. Schein, op. cit., p. 70.

${ }^{28}$ Cf. Pitt-Rivers, J. Honra e posição social. In: Peristiany, J. G. Honra e vergonha. Valores das sociedades mediterrânicas. Lisboa: Fundação Calouste Gunbenkian, 1988, p. 13. Em seu artigo, PittRivers alerta que os princípios da honra, embora universais, estão revestidos por concepções que não são exatamente equivalentes de região para região. Embora sabendo que o mundo homérico representa uma realidade bem particular e, como tal, tem suas especificidades, é possível utilizar as conceituações dadas por Pitt-Rivers, uma vez que essas se referem às estruturas gerais do conceito.
} 
Em uma sociedade de confronto na qual, para ser reconhecido, é preciso derrotar rivais em uma competição incessante pela glória, cada indivíduo está colocado sob o olhar do outro. O herói homérico é o que os outros veem dele. Sua identidade é construída dessa maneira, depende de sua avaliação social. ${ }^{29}$ A honra de um homem implica não somente a preferência por uma determinada forma de conduta, mas também o direito a certa forma de tratamento. A posição social estabelece-se pelo reconhecimento de certa identidade social. $^{30}$ Os reis homéricos constroem sua identidade cercando-se de elementos de sacralidade e um desses elementos é a timé recebida dos deuses, que faz com que o basileús aproxime-se cada vez mais do divino, tornando-o assim, um ser diferenciado dos demais.

Segundo Adkins, ${ }^{31}$ a timé do herói delimita sua posição em uma escala social cujo topo são os deuses imortais. Levando-se em consideração que, no universo dos poemas, o sagrado é indissociável das demais esferas do cosmos, constata-se que o mundo dos deuses é governado pelos mesmos valores que organizam o mundo dos homens. Compartilhando dos mesmos valores, desejos, sentimentos, o que diferencia o ser humano das divindades é o fato de estas não conhecerem a morte - são athánatoi (imortais) - e terem mais timé que os mortais: "Sua força é maior, sua honra, seu poder". ${ }^{32}$ Os deuses têm os mesmos atributos que os seres humanos, porém em maior quantidade. $\mathrm{O}$ homem homérico assim concebe os seus deuses, pois só conhecem um sistema de valores, o seu próprio, e é a imagem deste sistema que constroem sua representação das divindades.

Assim como os homens, também os deuses preocupam-se em obter timé e preocupam-se ainda mais se a perderem. No canto VII da Ilíada, ${ }^{34}$ vê-se Posêidon inseguro com um muro construído pelos aqueus em Troia. A fama (kléos) da muralha pode fazer com que os mortais esqueçam-se daquela que Posêidon e Apolo construíram com bastante esforço em Troia, a pedido do antigo rei da cidade, Laomedonte, pai de Príamo. O deus dos mares assim se queixa com Zeus:

[...] Na terra infinita haverá,

Zeus, um mortal capaz de alçar a mente dos deuses?

\footnotetext{
${ }^{29}$ Cf. Vernant, op. cit, p. 407.

${ }^{30}$ Cf. Pitt-Rivers, op. cit., p. 14.

${ }^{31}$ Cf. Adkins, A. W. H. Homeric gods and the values of Homeric society. Journal of Hellenic studies. London, vol. XCII, p. 3, 1972.

${ }^{32}$ Cf. Ilíada IX, 499.

${ }^{33}$ Cf. Adkins, op. cit., p. 1 e 7.

${ }^{34}$ Cf. Ilíada VII, 445-54.
} 
É ver como os Aqueus, longos-cabelos, ousam erguer um muro protetor das naus, e um fosso ao derredor escavam, sem mesmo ofertar uma hecatombe aos numes! Tanto quanto a Aurora se estende, será vasta a fama deste feito, e fará que se olvide o renome do muro que, para Laomedonte, Febo e eu levantamos, penoso labor.

Irritado Zeus responde ao irmão: ${ }^{.35}$

[...] Um pensamento assim, só a um deus inferior a ti em valentia e força poderia ocorrer; teu renome (kléos) irá sempre tão longe quanto a Aurora.

De acordo com Zeus, alguns deuses podem ter esse temor de serem subjugados pelo kléos dos homens e perderem timé, mas não Posêidon, que é poderoso o suficiente para não se preocupar com isso. Vê-se nessas passagens que o deus dos mares está mais preocupado com o kléos do que com a timé. Porém seu receio em não receber hecatombes (sacrifícios) por parte dos construtores do muro é justificável, uma vez que são as oferendas dos mortais, juntamente com a Moira, que dão a timé aos deuses. Cabe aos homens honrarem os deuses para deles conseguirem a philía. ${ }^{36}$

No mundo homérico, a prosperidade e o destaque social de um indivíduo são considerados presentes dos deuses, pois demonstram sua proximidade com o divino. $\mathrm{O}$ basileús, sendo o maior na escala social, tem mais timé dada pelos deuses. Aquele que recebe mais timé demonstra maior proximidade com as divindades. Os deuses, em Homero, não concebem benéficios aos seres humanos em uma vida após a morte; quanto mais proeminente é um homem em vida, mais demonstra que os deuses o estão protegendo e mantêm com ele uma relação de philía. $^{37}$

\footnotetext{
${ }^{35}$ Cf. Ilíada VII, 456-9.

${ }^{36}$ Comumente traduzido como "amizade" ou, ainda, "amor". No entanto, para Adkins, op. cit., p. 12, nenhuma das duas traduções expressa o sentido da palavra, devendo permanecer intraduzível, pois tem um sentido bastante especifico em Homero. Localiza-se no contexto das relações de reciprocidade do mundo homérico. Para maiores informações cf. Donlan, W. The social groups of Dark Age Greece. Classical Philology. Chicago, vol LXXX, n. 4, p. 293-308, 1985; Gill, C.; Postlethwaite, N.; Seaford, R. (org.), Reciprocity in ancient Greece. Oxford: University Press, 1998; Villela, J. L. M. A dívida e a diferença. Reflexões a respeito da reciprocidade. Revista de antropologia. São Paulo, vol. XLIV, p. 185220, 2001; Seaford, R. Reciprocity and ritual. Homer and tragedy in the developing city-state. Oxford: Clarendon, 2000.

${ }^{37}$ Cf. Adkins, op. cit., p. 15.
} 
A honra reservada ao herói homérico não é meramente uma abstração. Para Schein, ${ }^{38}$ o significado básico de timé seria "recompensa" ou "valor", em um sentido tangível. Para o autor, a palavra pode ser usada para designar uma mulher como Briseida, que era o géras — ou a dádiva de honra — de Aquiles, como também para designar assentos de honra, taças cheias de vinho, carnes e lotes de terra - como os do discurso de Sarpédon. Finkelberg ${ }^{39}$ argumenta que "honra" não é uma tradução precisa para o termo timé, ${ }^{40}$ dado o seu sentido abstrato. A autora concorda com a visão de Schein, ao conceber timé como algo palpável. Para ambos, Homero vê a honra como algo inseparável de presentes, possessões, proeminência nos banquetes.

Antes de prosseguir, é necessário delimitar certa diferenciação entre os dois termos em debate. Apesar de sutil, há uma importante diferença entre géras e timé. Para Benveniste, ${ }^{41}$ o primeiro é concedido ao herói pelos seus contemporâneos, enquanto o segundo é concedido pelo destino e pelas divindades, faz parte do quinhão de cada um. Assim, ninguém pode questionar a legitimidade desse apanágio.

Conforme as palavras de Odisseu: ${ }^{42}$ "É grande a ira de um rei, da progênie de Zeus. Honra lhe inspira o deus [timè d'ek Diós esti] astucioso que o ama!” A timé se define como uma dignidade de origem divina. Compreende não só o poder, mas também privilégios de respeito e rendimentos materiais. Assim sendo, a timé se distingue do geras, que é uma prestação material e ocasional concedida ao soberano ou a um herói pelos homens.

Adkins (1972: p. 5-6) refere-se à timé como possessões acrescidas de status, mas não somente isso. Essa palavra também carrega uma forte carga emotiva. Quando não é possível a restituição ou a substituição da timé perdida, a resposta imediata daquele que a perdeu é agir com violência. ${ }^{43}$ A resposta imediata de Aquiles à tomada de Briseida é o desejo de matar Agamêmnon: ${ }^{44}$

No peito hirsuto do Peleide [Aquiles] a angústia

\footnotetext{
${ }^{38}$ Cf. Schein, op. cit., p. 71.

${ }^{39}$ Cf. Finkelberg, M. Timē and aretē in Homer. Classical Quarterly. Oxford, vol. XLVIII, n. 1, p. 16, 1998.

${ }^{40}$ De acordo com a autora, a tradução apropriada para o termo timé, na maioria dos contextos da Ilíada, poderia ser status e/ ou "prestígio".

${ }^{41}$ Cf. Benveniste, op. cit., p. 51-2.

${ }^{42}$ Cf. Ilíada II, 196-7.

${ }^{43}$ Conforme Pitt-Rivers, op. cit., p. 20, "a prova final da honra é, em última análise, a violência física, e quando outros métodos falham existe a obrigação de recorrer a ela não só num código de honra formal como em meios sociais que não admitem esse código".

${ }^{44}$ Cf. Ilíada I, 188-94.
} 
assoma. O coração partido em dois, hesita. $\mathrm{Ou}$ arranca do flanco a espada pontiaguda e afastando os demais abate o Atreide [Agamêmnon] no ato, ou reprime o furor, doma a revolta no ânimo. Tudo isso lhe rodava no íntimo e, entretanto, ia sacando da bainha o gládio enorme.

Somente a intervenção da deusa Atena, prometendo-lhe restituição da ofensa recebida, consegue acalmar-lhe os ânimos. Diz a deusa: ${ }^{45}$
Descendo do alto céu, para acalmar-te a ira (se caso me obedeces), vim a mando de Hera, deusa dos braços brancos, que por ambos vela [Aquiles $e$ Agamêmnon]. Vamos, pára essa briga! Deixa em paz a espada! Insulta-o com palavras, sim, o quanto queiras. Agora vou dizer-te o que se cumprirá: um dia hão de pagar-te o triplo em dons esplêndidos como preço da afronta. Acalma-te e obedece.

Como no mundo homérico o valor de um homem está ligado a sua reputação, toda ofensa a sua dignidade, todo ato ou comentário que atinja seu prestígio serão sentidos pela vítima como uma forma de rebaixar ou destruir seu ser, sua virtude íntima, e de consumar sua queda. Desonrado, aquele que não conseguiu que o homem que o ofendeu pague pelo ultraje perde, com sua timé, o renome, o lugar na hierarquia e os privilégios. Separado das solidariedades antigas, afastado do grupo de seus pares, só lhe resta a condição de kakós, torna-se um errante, sem país ou sem raízes, é um exilado desprezível, um homem sem nenhum valor. ${ }^{46}$ Aquiles, ainda ofendido pela afronta de Agamêmnon, exclama: ${ }^{47}$ "Sempre recordo como o Atreide [Agamêmnon] entre os meus pares tratou-me: um sem-pátria, um qualquer..."

Ao tomar Briseida de Aquiles, Agamêmnon fere o herói no seu ponto mais sensível. O rei o despoja de seu géras, isto é, da parte de honra do butim com a qual o haviàm gratificado. ${ }^{48}$ Além da vantagem material que o géras proporciona, vale também

\footnotetext{
${ }^{45}$ Cf. Ilíada I, 207-14.

${ }^{46}$ Cf. Vernant, op. cit., p. 408.

${ }^{47}$ Cf. Ilíada IX, 647-9.

${ }^{48}$ No artigo de A. T. Murray (On the disposition of spoil in the homeric poems. American Journal of Philology. Baltimore, vol. XXXVIII, n. 2, p. 186-193, 1917), vê-se uma certa ambiguidade na Ilíada quanto à questão da disposição dos espólios de guerra. $\mathrm{O}$ autor cita várias referências em que é claro que Aquiles recebeu seu geras do conjunto dos aqueus. No canto XVI (Il., 56), o herói assim se refere a Briseida: "A moça que os Aqueus concederam-me em prêmio [géras]". Porém, no canto IX (Il., 367-9), Aquiles diz que o recebeu de Agamêmnon: "O prêmio [géras], Agamêmnon, de quem o recebi, de mim à bruta o arrebatou com hýbris ultrajante!" Ao final, Murray (op. cit., p. 193) conclui que os espólios
} 
como símbolo de prestígio, como consagração de uma supremacia social. Um géras é um privilégio excepcional, uma prestação concedida a título especial, como reconhecimento de uma superioridade de posição — como no caso de Agamêmnon ou de valor e façanha - como no caso de Aquiles. Tirar o géras de Aquiles é, de certo modo, negar-lhe a excelência no combate, a qualidade heroica que nele todos reconhecem. ${ }^{49}$ Privado de seu géras, Aquiles sente-se desonrado, torna-se átimos. Sem honra, o herói deseja retornar à pátria: ${ }^{50}$ "Agora volto a Fítia. À casa, em naves curvas, mais vale retornar, que imaginar-me aqui, sem honra (átimos), a recolher-te espólios e tesouros". Uma vez que as deusas Atena e Hera o proibiram de matar Agamêmnon para apagar sua desonra, Aquiles acaba caindo na situação de átimos. Deixar uma afronta por vingar é deixar a própria honra num estado de profanação e equivale à covardia. A relação honra/ coragem e desonra/ covardia resulta diretamente da estrutura da noção de honra, conforme argumenta Pitt-Rivers. ${ }^{51}$

A lógica da honra heroica é o tudo ou nada. Entre a glória imperecível e o último grau da ignomínia, não há posição intermediária para Aquiles. Qualquer ofensa a sua dignidade provoca um efeito que oscila de um extremo ao outro. Isso ocorre pois é atingido o valor de um código que é preciso aceitar sem reservas, sob pena de depreciálo por inteiro. ${ }^{52}$ De acordo com Schein, ${ }^{53}$ a ofensa feita a Aquiles corresponde a uma violação de uma norma social. Ofender a honra do herói equivale a colocar no mesmo plano o covarde e o valoroso. De acordo com as próprias palavras do herói: ${ }^{54}$

O Atreide nunca me convencerá

[...] Não há recompensa no incessante combate contra os inimigos; lote igual se destina ao valente e ao inerme; prestam honras [timé] iguais ao herói [esthlós] e ao poltrão [kakós]; morre tanto o pugnaz, quanto o que nada faz.

pertencem à coletividade do exército aqueu e por isso é citado como doador do géras. Porém, é necessário que o líder da pilhagem assuma o controle da distribuição. No caso da Ilíada, é Agamêmnon que assume esse papel. Sendo o comandante-em-chefe da expedição aqueia a Tróia, é ele que tem a preponderância na distribuição dos espólios. Em sua definição de geras, Benveniste, op. cit., p. 44 reforça esse aspecto coletivo que a noção traz: "O géras, portanto, é uma vantagem material, conferida pelo conjunto dos membros de um grupo social quando de uma partilha, durante a apropriação de despojos (saque de uma cidade), por meio de uma reunião prévia de todo esse butim, do qual justamente é retirado esse géras, parte do chefe". No entanto, Benveniste frisa que é sempre Agamêmnon quem distribui aos guerreiros e demais reis o géras de cada um, suas partes de honra.

${ }^{49}$ Cf. Vernant, J. P. A Bela Morte e o cadáver ultrajado. Discurso. São Paulo, vol. IX, p. 34-35, 1978.

${ }^{50}$ Cf. Ilíada I, 169-71.

${ }^{51}$ Cf. Pitt-Rivers, op. cit., p. 18.

${ }^{52}$ Cf. Vernant, op. cit., p. 36.

${ }^{53}$ Cf. Schein, op. cit., p. 71.

${ }^{54}$ Cf. Ilíada IX, 315-20. 
Restituir a timé perdida de Aquiles não é uma tarefa tão simples para Agamêmnon. ${ }^{55} \mathrm{Na}$ tentativa de aplacar a ira do herói ultrajado, o rei de Micenas declara ter sido culpa da $a e^{56}$ que o cegou e o fez tomar a cativa de Aquiles: ${ }^{57}$

Quero justificar-me ante o Peleide.

[...] Não sou culpado,

mas Zeus, a Moira e a negronoctâmbula Erínia;

na ágora, eles cegaram-me o siso, funestos, no dia em que tomei o prêmio do Aquileu.

Mas o que fazer? Perpassa um nume e perfaz tudo:

Ate, a filha maior do pai Zeus, atroz, multi-

-enganosa. Pés lépidos, não pisa a terra;

Anda sobre a cabeça dos homens e ao cabo

os arruína; um depois do outro, ela os burla e enreda.

O próprio Zeus, como se diz, o mais potente

entre os deuses e os homens, ela já iludiu.

Agamêmnon manda uma embaixada — Odisseu, Ájax e Fênix — para oferecer a Aquiles reparação pública da ofensa que lhe fora infligida ao tomar-lhe a cativa Briseida, seu géras, a parte de honra que os Aqueus lhe haviam atribuído pela sua excepcional valentia no campo de batalha. Odisseu enumera os inúmeros presentes que Agamêmnon está disposto a dar-lhe como retratação: bacias; trípodes; talentos de ouro; cavalos; sete cativas hábeis nos trabalhos manuais, entre elas Briseida, que ele devolve

\footnotetext{
${ }^{55}$ A restituição da honra é de primordial importância dentro dessa moral. A satisfação pode ser obtida por desculpas ou pode exigir uma vingança, se as desculpas não forem rapidamente apresentadas ou não forem aceitas. As intenções são de extrema relevância para o restabelecimento da honra porque demonstram o sentimento e o caráter dos quais a honra, como conduta, deriva. As desculpas, quando apresentadas, tomam, portanto, a forma de uma negação da intenção de ofender. A falta de intenção reduz a gravidade do insulto, torna as desculpas mais fáceis de se aceitar. Dizer que um ato foi cometido sem intenção é contar com alguma benevolência do interlocutor, a não ser que este tenha sido gravemente ofendido, pois, em se tratando de honra, as ações são mais claras que as intenções, cf. Pitt-Rivers, op. cit., p. 18.

${ }^{56}$ Em uma perspectiva psicanalítica, E. R. Dodds (Os gregos e o irracional. São Paulo: Escuta, 2002) define áte como um estado mental. Para o autor, trata-se de um bloqueio temporário ou confusão no estado normal de consciência. Refere-se a uma situação de insanidade parcial e temporária e, como toda insanidade, é atribuída não a causas fisiológicas ou psicológicas, mas a uma intervenção externa e "demoníaca". Dodds ainda salienta que não se deve confundir áte com perversidade, culpa ou ainda fuga das responsabilidades, trata-se apenas de um inexplicável erro. $\mathrm{O}$ autor trabalha com os conceitos de "cultura da vergonha e da honra" - que se aplicaria à sociedade homérica — em oposição às "culturas da culpa e do dever". Quando um grego agiu mal - como no caso de Agamêmnon, que se apropriou da cativa de Aquiles - , não tem a sensação de ser culpado de um pecado, mas de ter sido indigno do que ele mesmo e os outros esperavam dele, de ter perdido a honra. Quando age bem, não é porque se conformou a uma regra que lhe seria imposta, uma regra de dever decretada por Deus ou pelo imperativo categórico de uma razão universal. É porque cedeu à atração de valores, ao mesmo tempo estéticos e morais, o Belo e o Bem.
}

${ }^{57}$ Cf. Ilíada XIX, 86-96. 
sem ter tocado; uma de suas filhas, à sua escolha, para tomar como esposa; sete de suas melhores cidades, que o honrarão com oferendas, como a um deus. ${ }^{58}$

Aquiles recusa. Mesmo se lhe oferecessem dez vezes mais, recusaria. Os presentes de Agamêmnon lhe são odiosos: ${ }^{59}$

Odeio as dádivas

vindas de sua mão. Valem menos do que um pêlo.

Dez, vinte vezes mais me desse do que tem, [...] nem mesmo assim persuadiria o Atreide meu coração, enquanto não pagasse a ofensa, ânimo-abrasiva áscua em meu peito.

A própria opulência dos presentes aparece como irrisão para um herói como Aquiles, que, quando se empenha no combate, põe em jogo não trípodes ou ouro, mas sua própria vida: 60 "Nada me adveio, após jogar a vida (psyché) e tanto padecer, a lutar, expondo-me sem pausa".

De acordo com Adkins, ${ }^{61}$ a restituição da timé não é uma questão meramente matemática. Se um herói homérico perde uma determinada quantidade de timé, a simples restauração de quantidade equivalente — ou, no caso de Agamêmnon e Aquiles, bem superior — não é suficiente para aplacar a ira do ofendido. Como o autor trabalha com a ideia de que timé refere-se a bens materiais acrescidos de uma alta carga emotiva, é preciso muito mais do que presentes para restaurar a timé perdida. Além disso, é necessário acalmar os sentimentos feridos e restabelecer a autoconfiança do herói.

Aquiles não lutâ por bens materiais. Não são as vantagens materiais nem o primado da condição nem as marcas de honra que têm o poder de levar um homem a empenhar sua psyché em duelos sem trégua, nos quais se conquista a glória. Se fosse somente isso, não se encontraria um só guerreiro que não se escondesse no momento em que fosse preciso arriscar-se a perder tudo no jogo. Isso é visível nas palavras de Sarpédon a Glauco: ${ }^{62}$

Amigo, se fugindo desta guerra acaso da velhice e da morte fôssemos libertos,

\footnotetext{
${ }^{58}$ Cf. Ilíada IX, 263-97.

${ }^{59}$ Cf. Ilíada IX, 378-88.

${ }^{60}$ Cf. Ilíada IX, 321-2.

${ }^{61}$ Cf. Adkins, op. cit., p. 303.

${ }^{62}$ Cf. Ilíada XII, 322-8.
} 
eu não me lançaria à luta entre os primeiros nem à gloria da pugna ora te exortaria; mas as Queres da morte nos rondam, miríades, às quais homem algum escapa nem evita; logo, é dar glória a alguém ou deste nos gloriarmos.

É pela timé que Aquiles luta, porém o herói não a avalia pelo crivo do poder real ou das honras que os súditos prestam ao seu senhor. Tentando convencer Aquiles a aceitar os presentes de Agamêmnon, Fênix suplica, ${ }^{63}$

Aceita os presentes, socorre os Gregos. Como um deus, eles te tratarão. Mas se entrar no combate homicida sem dons, mesmo vencendo, não colheras glória igual.

Aquiles não quer essa honra. O herói diz a Fênix que deseja a honra que vem de Zeus: ${ }^{64}$

Velho pai, dileto-

-de-Zeus, desdenho glórias (timé). Só cuido daquelas a que me predestina o Sumo [Zeus] e que comigo, enquanto eu respire, há de estar, junto às naus curvas, enquanto eu me mover.

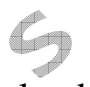

Aquiles desdenha da honra laudatória, preocupa-se apenas em ser honrado pelo destino, um destino de morte iminente no campo de batalha, ${ }^{65}$ que lhe garantirá a glória imortal cantada pelos aedos.

O caráter bélico da realeza homérica está ligado aos aspectos sagrados do exercício do poder. Em seu estudo sobre as características da realeza, Valeri conclui: ${ }^{66}$

O rei é, pois, um guerreiro, um conquistador, indissoluvelmente ligado ao uso da força. Mas esta força não é vista como um simples fato físico; a sua superioridade militar, o seu sucesso, parecem excepcionais e, por isso, não humanos. Daqui a considerá-lo divino vai um passo.

\footnotetext{
${ }^{63}$ Cf. Ilíada IX, 603-6.

${ }^{64} \mathrm{Cf}$. Ilíada IX, 607-11.

${ }^{65}$ Sua mãe Tétis, logo no início do poema prevê a morte de Aquiles (Cf. Ilíada I, 414-7): “Ai de mim! Te criei nutrido de infortúnio: Sem lágrimas, sem dor, assim eu te quisera sentado junto às naves, pois te espreita a Moira, tens vida breve".

${ }^{66}$ Cf. Valeri, V. Realeza. In: Romano, R. (org.) Enciclopédia Einaudi. Vol. XXX: Religião-rito. Lisboa: Imprensa Nacional/ Casa da Moeda, 1994, p. 421.
} 
É isso que faz o basileús homérico diferente dos demais membros da sociedade. É essa ligação com as divindades que o transforma em herói, hierarquicamente acima dos homens comuns, mas ainda assim mortal.

\section{Referências}

ARISTÓTELES. A Política. Tradução de Roberto Leal Ferreira. São Paulo: Martins Fontes, 2002.

ADKINS, A. W. H. Merit and responsibility. A study in Greek values. Chicago: University of Chicago Press, 1975.

. Homeric gods and the values of Homeric society. Journal of Hellenic studies. London, vol. XCII, p. 1-19, 1972.

BENVENISTE, E. O vocabulário das instituições indo-europeias. Vol. II: Poder, Direito, Religião. Campinas: UNICAMP, 1995.

DODDS, E. R. Os gregos e o irracional. São Paulo: Escuta, 2002.

DONLAN, W. The social groups of Dark Age Greece. Classical Philology. Chicago, vol. LXXX, n. 4, p. 293-308, 1985.

FINKELBERG, M. Timēe e aretē in Homer. Classical Quarterly. Oxford, vol. XLVIII, n. 1, p. 14-28, 1998.

FINLEY, M. I. O mundo de Ulisses. Lisboa: Presença, 1988.

GILL, C.; POSTLETHWAITE, N.; SEAFORD, R. (org.). Reciprocity in ancient Greece. Oxford: University Press, 1998.

HOMERO. Ilíada. Tradução de Haroldo de Campos. São Paulo: Arx, 2003. Vol. I/ II.

McGLEW, J. F. Tyranny and political culture in Ancient Greece. Ithaca: Cornell University Press, 1996.

MURRAY, A. T. On the disposition of spoil in the homeric poems. American Journal of Philology. Baltimore, vol. XXXVIII, n. 2, p. 186-93, 1917. 
PITT-RIVERS, J. Honra e posição social. In: PERISTIANY, J. G. (org.). Honra e vergonha: valores das sociedades mediterrânicas. Lisboa: Gunbenkian, 1988, p. 11-59.

SCHEIN, S. L. The mortal hero. An introduction to Homer's “Iliad”. Berkeley: University of California Press, 1984.

SEAFORD, R. Reciprocity and ritual. Homer and tragedy in the developing city-state. Oxford: Clarendon, 2000.

THEML, N. As realezas em Homero: géras e timé. Phoînix. Rio de Janeiro, vol. I, p.147-55, 1995.

VALERI, V. Realeza. In: ROMANO, R. (org.) Enciclopédia Einaudi. Vol. XXX: Religião-rito. Lisboa: Imprensa Nacional/ Casa da Moeda, 1994, p. 415-45.

VAN WEES, H. Kings in combat: battles and heroes in the "Iliad". Classical Quarterly. Oxford, vol. XXXVIII, n. 1, p. 1-24, 1988.

VERNANT, J.P. Entre o mito e a política. São Paulo: Edusp, 2001.

. A Bela Morte e o cadáver ultrajado. Discurso. São Paulo, vol. IX, p. 3162, 1978.

VILLELA, J. L. M. A dívida e a diferença. Reflexões a respeito da reciprocidade. Revista de Antropologia. São Paulo, vol. XLIV, p. 185-220, 2001. 